See discussions, stats, and author profiles for this publication at: https://www.researchgate.net/publication/264819820

\title{
Born global networks: The role of connectors
}

Article in European Journal of International Management · October 2012

DOI: 10.1504/EJIM.2012.049642

3 authors:

Adele R. Smith

National University of Ireland, Galway

1 PUBLICATION 5 CITATIONS

SEE PROFILE

6. David G. Collings

Dublin City University

98 PUBLICATIONS 4,381 CITATIONS

SEE PROFILE

Some of the authors of this publication are also working on these related projects:

Oxford Handbook of Talent Management View project

Book on macro-perspectives on talent management View project
National University of Ireland, Galway 16 PUBLICATIONS 183 CITATIONS

SEE PROFILE 


\title{
Born global networks: the role of connectors
}

\author{
Adele R. Smith and Paul A. Ryan* \\ Department of Management, \\ Centre for Innovation \& Structural Change (CISC), \\ J.E. Cairnes Graduate School of Business \& Public Policy, \\ NUI, Galway, Ireland \\ Email: a.smith15@nuigalway.ie \\ Email: paul.a.ryan@nuigalway.ie \\ *Corresponding author
}

\section{David G. Collings}

Dublin City University Business School,

Dublin City University,

Dublin 9, Ireland

Email: david.collings@dcu.ie

\begin{abstract}
The nature of born global firms which from inception, seek to derive significant competitive advantage from the use of resources and the sales of outputs in multiple countries remains poorly understood. Given the lack of resources which born globals tend to have compared with larger international competitors the importance of social capital and network ties in addressing their liabilities of newness and smallness have received some attention. However, how these network ties actually operate and the nuances inside of these networks are as yet not fully understood. This paper seeks to address this knowledge gap by attempting to unpack the black box of the social networks and connectors which born globals draw upon in their internationalisation efforts. Based on a study of the indigenous Irish digital, film and TV production industry, our research points to a suite of both weak and strong connectors which facilitate the internationalisation of the firms in our sample.
\end{abstract}

Keywords: born globals; connectors; international entrepreneurship; internationalisation; networks; social network analysis.

Reference to this paper should be made as follows: Smith, A.R., Ryan, P.A. and Collings, D.G. (2012) 'Born global networks: the role of connectors', European J. International Management, Vol. 6, No. 5, pp.566-589.

Biographical notes: Adele R. Smith is a graduate student at the Cairnes Business School, National University of Ireland, Galway. Her research focuses on international new ventures, technological entrepreneurship and born globals.

Paul A. Ryan is a Lecturer in Strategic Management, Entrepreneurship and International Business at National University of Ireland, Galway. His research focuses on industrial clusters and technological entrepreneurship. $\mathrm{He}$ previously lectured at University College Dublin. He completed his $\mathrm{PhD}$ at the Judge Institute of Management Studies, University of Cambridge. His work has been published in the International Journal of Innovation \& Technology Management, Journal of Management Research and Organizational Research Methods.

Copyright (C) 2012 Inderscience Enterprises Ltd. 
David G. Collings is Professor of HRM at Dublin City University Business School. He previously held faculty positions at NUI Galway and the University of Sheffield. He research interests focus on the management of people in MNEs. His work in these areas has been published in outlets such as Human Resource Management, Industrial and Labor Relations Review and Journal of Vocational Behavior. He is editor of Human Resource Management Journal.

\section{Introduction}

The means through which firms internationalise has represented an important concern for academic study in the international business literature. More recently the focus has shifted to consider the internationalisation of small firms with a particular emphasis on born global firms. A key characteristic of born globals is that they rapidly internationalise their operations and further in ways that circumvent many existing international business research paradigms (Gabrielsson and Kirpalani, 2004). While recognising a degree of controversy around the definition of born global firms, we adopt Oviatt and McDougall's (1994, p.49), simple definition of a firm that "from inception, seeks to derive significant competitive advantage from the use of resources and the sales of outputs in multiple countries".

While our knowledge of born globals has advanced significantly over the past decade or so, our understanding is far from complete. For example, given the lack of resources which born globals tend to have compared with larger international competitors the importance of social capital and network ties in addressing their liabilities of newness and smallness have received some attention (Coviello and Munro, 1995). However, how these network ties actually operate and the nuances inside of these networks are as yet not fully understood. This paper seeks to address this knowledge gap by attempting to unpack the black box of the social networks and connectors which born globals draw upon in their internationalisation efforts. It addresses the questions of who are the key connectors in the network of a born global and how do these networks play out in practice as firms reach out to potential customers in the global marketplace?

Arguably our understanding of born global has been limited by a rather narrow focus on pure software firms. Thus, further research in sectors beyond software is central to the progression of the field. In this regard, this paper studies the born global phenomenon in the digital, film and TV production industry. While we acknowledge that this sector could be considered to be a subset of the software industry, we argue that the characteristics of the sector are relatively different. For firms in this sector operating in small economies such as Ireland, this industry is almost by definition international. Given the small size of the Irish market combined with the centrality of Hollywood to the sector, indigenous firms must rather quickly tap into the global marketplace if they stand any chance of being successful.

We begin by reviewing the literature which underpins our study. We then outline the methods adopted in our empirical study. Following the presentation of our findings we conclude by considering the import of our findings and outlining some directions for future study. 


\section{Literature review}

\subsection{International entrepreneurship}

Our understanding of international entrepreneurship has developed and evolved significantly over the past decade. A key part of this evolution has been improved understanding of the conceptual and intellectual boundaries of the field. Dimitratos and Plakoyiannaki (2003) further extended the work of McDougall and Ovaitt (2003) in developing a definition of international entrepreneurship as:

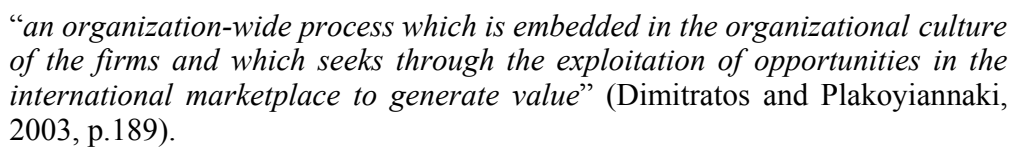

"an organization-wide process which is embedded in the organizational culture of the firms and which seeks through the exploitation of opportunities in the international marketplace to generate value" (Dimitratos and Plakoyiannaki, 2003, p.189).

Further, Dimitratos and Plakoyiannaki (2003) have linked five different fundamentals of international entrepreneurship. Firstly, it is an organisation-wide occurrence, which extends across all degrees of the chain of command within the organisation and its geographical limits (Dimitratos and Plakoyiannaki, 2003). Second, it is a dynamic and evolving process, i.e. a lengthy process in terms of evitable results (Zahra and George, 2002). Third, it is fixed within the organisational culture of the enterprise and it may be an important contextual issue to international entrepreneurship motives (Liesch and Knight, 1999; Naranjo-Valencia et al., 2011). Further, it revolves around the detection of opportunities in the international market environment (Dimitratos and Plakoyiannaki, 2003). Finally, it involves setting an aim at value creation for the company, regardless if the profits may seem in the long-distant future (Dimitratos and Plakoyiannaki, 2003).

Oviatt and McDougall (2005) advocate that the field of international entrepreneurship is an important topic, from which the term 'international new venture' is found within and explaining its acceleration of internationalisation process is at the centre point of research (Hurmerinta-Peltomaki, 2004). These new ventures are those, which are found actively engaging in international activity at an early stage in the business lifecycle, which is a form of early internationalisation. In the following sections, we unpack some of the key streams of literature relevant to our study.

\subsection{Internationalisation theory}

Internationalisation is used to illustrate "the gradual, incremental pattern of a firm's expansion into international markets" (Erramilli et al., 1999, p.31) or as Rugman (1981) previously highlighted, it is the method firms use to establish markets internally, and where the internal pricing strategies permit that specific market to work cost-effectively, as in the case of external markets. Many researchers throughout the years have projected internationalisation theories which seek to examine how a firm becomes involved in internationalised operations as well as how firms build resource assurance in overseas markets (Erramilli et al., 1999). As Davidson (1980) outlines, such theories have been used to explore the market entry methods employed by such firms and also the market selection procedures which were carried out. Overall, there have been various studies carried out in the field of internationalisation over the past number of years, from the original work of Hymer in 1960, to the extensive research carried out by Johanson and 
Wiedersheim-Paul in 1975 which still continues today, along with Madsen and Servias (1997), Ovaitt and McDougall (1995), Ovaitt and McDougall (2005), Weerawardena et al. (2007) and Lopez et al. (2008) to name but a few.

\subsection{Internationalisation process models}

To some extent, the two traditional international process models which have appeared in Europe and the USA are relatively similar (for a recent discussion see Hotho and Champion, 2011). The former, and most dominant of the two has been labelled in an article by Andersen (1993), as "The Uppsala Internationalisation Model (U-M)" by Johanson and Wiedersheim-Paul (1975) and Johanson and Vahlne (1977). The latter has been constructed by Bilkey and Tesar (1977), Cavusgil (1980), Czinkota (1982) and Reid (1981) is known as "The Innovation-Related Internationalisation Model (I-M)".

In brief, such learning and innovation models have previously been used to examine both large firm and small firm modes of internationalisation as well as their international activities. However, research indicates that they describe only the procedure of change and fail to give an explanation for the scope or nature of approaches used by the firm in their development of activity stage. Further, given the type of rapid internationalising firms to be examined in this research, i.e. Born Globals, such models fail to describe the contradicting accelerating path which they follow. Therefore it is necessary to examine more recent models which seek to explain the internationalisation route followed by born globals, from a network perspective as research indicates this tends to be the approach taken by such.

\subsection{New network internationalisation models}

The network approach to internationalisation adapted by these following models can be used to get an insight into the firm's behavioural activities in relation to internationalisation. Based on the criticisms and suitability of the traditional models such as the Uppsala Model, further network models have been developed. The first model to be examined is known as the "Business Network Model" by Johanson and Vahlne (2003) which outlines the findings of their more recent research, indicating the changes from their previous traditional models as a result of advancements in the twenty-first century. The second conceptual framework and systems of relationships model to be examined is from the work of Weerawardena et al. (2007) which also seeks to get an insight into the mode taken by rapid internationalising firms.

Given the continual debate and need for a suitable model to examine the internationalisation route taken by rapid internationalising firms, Johanson and Vahlne (2003) have labelled their latest model as the "Business Network Model". Business networks can be referred to as interrelated business interactions, whereby an exchange between various firms and actors occur (Anderson et al., 1994).

Johanson and Vahlne's (2009) model below indicates a similar circular process, in that knowledge opportunities and the network position affect the relationship commitment decisions and the learning, creating and trust building, which results in altering the firm's knowledge opportunities and network position. The 2009 model is as shown in Figure 1.

However, as this is the most recent 'network' model, there are many more business network models developed prior to this, which are also under review within this investigation. 
Figure 1 The business network internationalisation process model (The 2009 version)

State

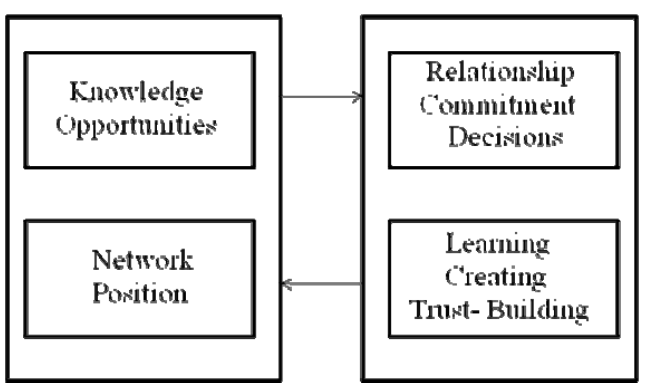

Source: Johanson and Vahlne (2009, p.1424)

\subsection{Conceptual framework and systems of relationships}

Given the shortcomings of the Uppsala model a new "conceptual framework and system of relationships" has been constructed (Weerawardena et al., 2007). This framework merges a firm's dynamic capabilities, and competitive advantage, which has been outlined by (Teece et al., 1997), as well as the organisational learning theory identified by Bell et al. (2002), Burpitt and Rondineli (1998) and Huber (1991).

Further to this it is believed that the process of constructing capabilities in a bornglobal firm are motivated by "entrepreneurial owner-managers with a global outlook" (Weerawardena et al., 2007), before they experience an international and learning direction. Figure 2 outlines the model (Weerawardena et al., 2007).

Figure 2 The proposed dynamic capability model of born global firm accelerated internationalisation

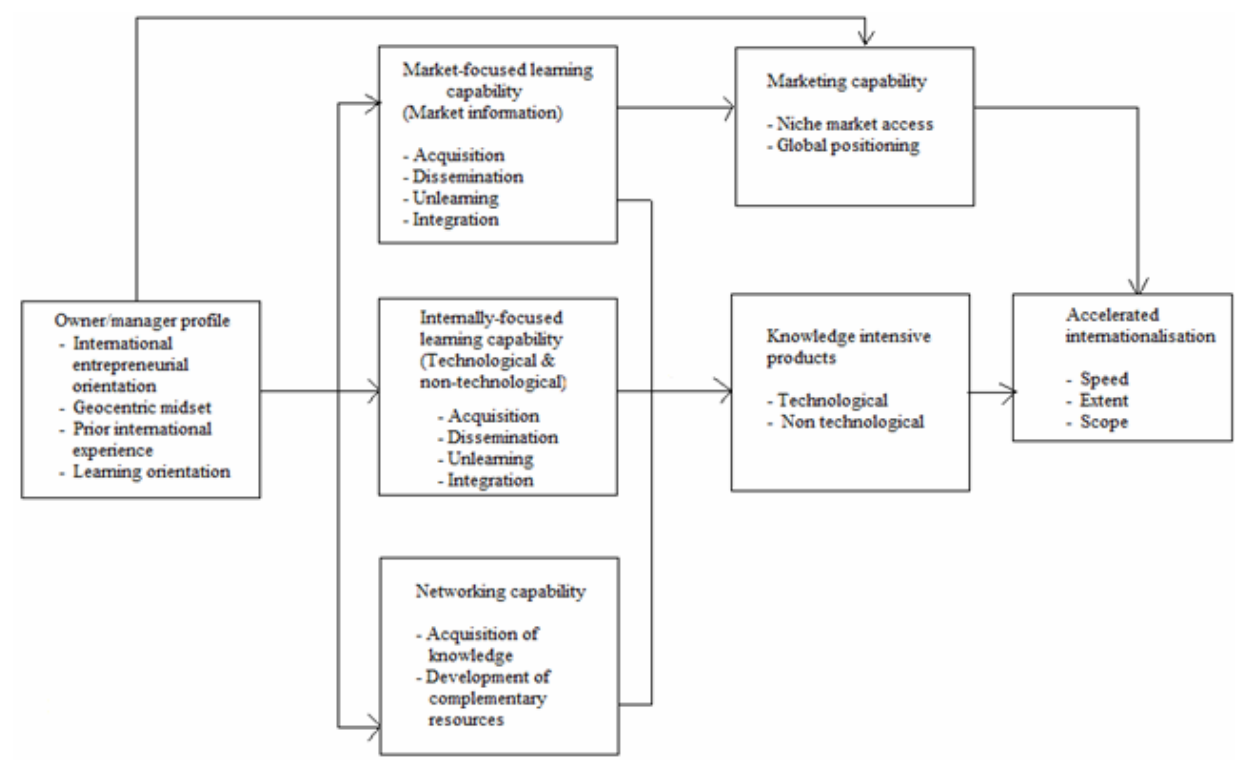

Source: Weerawardena et al. (2007, p.299) 
This model draws on organisational learning theory, which provides both a novel conceptualisation of the factors leading towards a firm's rapid internationalising, it also offers a direction on how to target the development of policies which are proposed to promote an increase in the number of firms internationalising (Weerawardena et al., 2007). Such a model proves to be substantial in terms of investigating further the Born Global phenomena, along with the mentioned business network theory proposed by Johanson and Vahlne (2003, 2009).

\subsection{The born global phenomenon}

The following conceptual framework (see Figure 3) adapted from Andersson and Wictor (2003) will be used to structure the overall direction of future research in this area, by examining in greater depth the variables which influence the internationalisation path taken by firms, which are further discussed, exploiting the network variable.

Figure 3 Conceptual framework (see online version for colours)

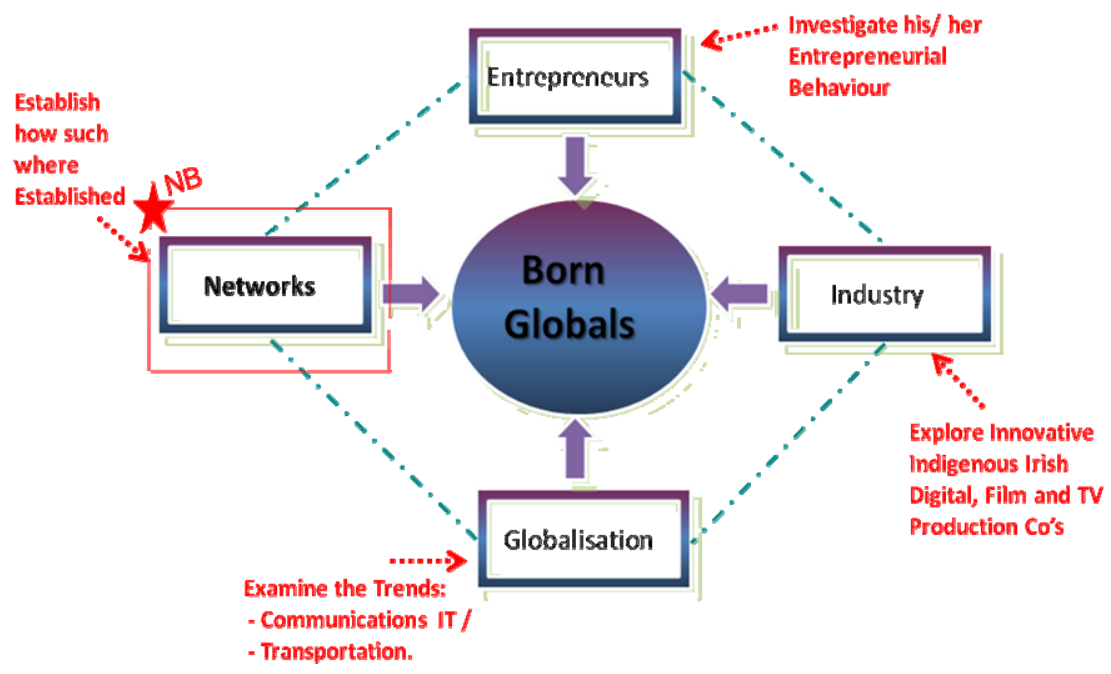

Source: Andersson and Wictor (2003. p.254)

Specifically, the variables include the 'entrepreneur', the selected 'industry', 'globalisation' as well as the 'network'. This paper specifically examines the 'network' variable. Further research in this area has been called for by many authors including Andersson and Wictor (2003), thus establishing how exactly networks have arisen and the role they play in the born global firm's internationalising process. Therefore using the framework constructed by Andersson and Wictor (2003) as well as incorporating the work of Weerawardena et al. (2007) this study seeks to draw rich information and fulfil research objectives as to how exactly such networks have been established in mentioned firms.

Previous research has indicated that networks are important for business start-up (Andersson and Wictor, 2003), and that new firms depend on relationships, be it with financiers, suppliers and/or customers (Oviatt and McDougall, 1995). While networks have been viewed as important in terms of international expansion, Rasmussen et al.'s (2000) empirical study found that many founders of born globals were not involved in networking during their establishment. However, given the level of debate, it has been 
established that 'networks' are important in terms of understanding a firm's international development, as well as its approach to local networking (Johannisson, 1994; Andersson and Wictor, 2003). The work of Coviello and Munro (1995) also highlights the importance of networking in terms of the entrepreneurial firm's international development. Such authors suggest that the mode of entry and market selection for certain SMEs is heavily 'shaped' by the 'network players' Coviello and Munro (1995), thus reiterate the importance of network analysis in terms of getting an insight into the path and patterns of internationalisation followed by such firms.

In addition to examining the 'network' variable, which has been outlined in the work of Andersson and Wictor (2003), this paper also adopts theories from the social network analysis) - Gladwell's theory of 'connectors' (Gladwell, 2000) and Granovetter's theory of strong/weak ties (Granovetter, 1973; Granovetter, 1983), which together will contribute to rich in-depth findings as to how exactly networks have been established and through which connectors internationalisation has been made possible.

\subsection{Social network theory}

The term social networks first appeared in research over 50 years ago, and since then an extensive review of the area has been carried out (Vivian and Sudweeks, 2003). Barnes (1954) has been recognised as the researcher that coined the term, social networks. In his study of a Norwegian island parish, he saw such an idea as an addition to social relations. The theory itself can apply to a wide range of human organisations i.e. from small groups of individuals to complete global nations. Human beings are also social creators and rather than living in isolation, people generally prefer to live together in communities, towns or large cities. Throughout our life time we become members of many social networks, expanding from our own families and friends to colleagues at, school, travel, work, interest groups and sports clubs. Therefore, it can be said our so called 'personal world' revolves around social networks. In order to get an insight into such social networks, social network theories such as Granovetter's "Strenght of Weak Ties", how different sets of relationships between various members of a social system affect behaviours and beliefs (Monge and Contractor, 2003). The findings from these theories collectively demonstrate a degree of precision to the notion of the old cliché - "it's not what you know, it's who you know, that really matters". While these theories enlighten the general social network theory, Allen's (1977) introduction of the technological gatekeeper provides a key point of departure for our study.

Relationships are at the centre of social network analysis, where they "indicate a connection between two or more people or things" (Haythornthwaite, 1996). As Haythornthwaite (1996) explains pairs of actors who continue to be part of a relationship are 'linked' by that particular relationship (e.g. pairs may be work colleagues), they can also be 'linked' together by a number of relationships (e.g. as well as work together, they may possibly socialise together). Haythornthwaite (1996) further explains how pairs of actors are 'tied' through the relationships they tend to sustain, therefore a tie portrays "the aggregate connection between pairs" (Haythornthwaite, 1996). From this it can be revealed that social network analysis concentrates on the precedent patterns between actors and relationships, as well as detecting the ties between pairs and examining the relationships which derive from such (Haythornthwaite, 1996).

In order to further explain the concept of tie strength which examines the ties connecting actors (Haythornthwaite, 1996), it is firstly important to gain an understanding of what defines a 'connector'. Stanley Milgram was one of the first to explore how human beings were connected, the findings indicated that 'a very small number of people 
are linked to everyone else in a few steps, and the rest of us are linked to the world through those special few' (Gladwell, 2000). These small numbers of individuals are referred to as "connectors", as they are those who link us up with the rest of the world, and bring us together with our social loop (Gladwell, 2000). Gladwell (2000) further describes connectors as individuals with a unique ability, which brings the world together, as they are seen as someone who knows everyone, i.e. a people person, as they have an exceptional natural knack of making friends and social connections. What makes a 'connector' important is the 'kinds of people they know', because of their tendency to engage in various different worlds, it is then because of this that they can connect the different niches, subcultures and worlds together (Gladwell, 2000). In order to explore the function of connectors Granovetter (1983) carried out an investigation of hundreds of employees, interviewing them in detail regarding their employment history and how they found their jobs. The majority of employees had found their jobs through "personal connections" these were mostly found to be "weak ties" (A sociologist's description of a friendly yet casual connection (Gladwell, 2000) or an acquaintance (Granovetter, 1995), outlining that selected individuals weren't getting their jobs through their close friends/ "strong ties" but rather through their acquaintances (Granovetter, 1983). Granovetter's interpretation of this was that we occupy the same world as our so called "close friends", e.g. work together, indicating that we have similar knowledge, however regarding our acquaintances, they operate in a very different world to that of us, and they are seen to symbolise a foundation for social power (Gladwell, 2000). Granovetter (1973) highlights the importance of "the strength of weak ties", as these are what we rely on to give us the needed power as well as provide us with new information or an entrance to opportunities and locations in which we do not belong. This is of critical importance for rapid internationalising born globals. Such people/information specialists are those who shape the course taken by social epidemics, and "with the slightest push - in just the right place - it can be tipped" (Gladwell, 2000). Further to this concept, the next part of the paper involves investigating briefly the technological gatekeeper, and their input regarding the flow of external knowledge in the organisational context.

\subsection{The gatekeeper phenomenon}

Thompson (1967) and March and Simon (1958) outline that social systems must be able to accumulate and process information from various external sources in order to direct decisions. However, processing is a time consuming and expensive game (Arrow, 1974). Tushman and Katz (1980) reiterate the work of other authors and states in order to deal with costs involved in processing, information can be processed by means of specialisation (Katz and Kahn, 1966; Thompson, 1967). Specialisation involves dealing with segments of the systems working environment. Further to this actors develop local orientation in addition to coding systems in order to transmit information sourced (Tushman and Katz, 1980). Actors who share their coding schemes prove to be more efficient as opposed to those who do not (Tushman and Katz, 1980). They indicate that while local information is being processed this in turn obstructs the encoding of information from external sources. The difficulty presented at this stage, deals with the complexity of communicating across many boundaries (Tushman and Katz, 1980). Tushman and Katz (1980) propose gatekeepers as a key means of bridging these holes.

Tushman and Katz (1980) describe gatekeepers as "boundary spanning individuals", as they are seen as links, which are strongly connected to the organisation i.e. internal colleagues as well as its external environments. In other words those that are deeply 
connected to both internal social groups and external knowledge sources, which have the ability to translate between both systems (Allen and Cohen, 1969; Allen, 1977 and Tushman and Scanlan, 1981). Shoemaker (1991) describes the gatekeeping procedure as:

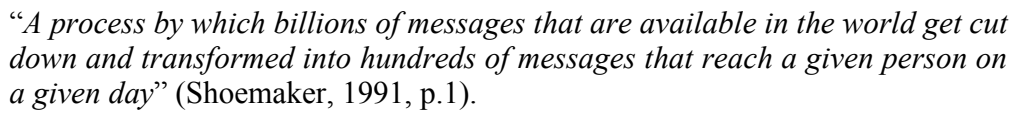

Gatekeepers aid in the flow of external information into the communication system, by a process involving two-steps (Tushman and Katz, 1980). Firstly, the gatekeeper has the ability to collect and understand the relevant external information and secondly, they are skilful individuals who can decode sourced information into a meaningful format for those internal colleagues (Tushman and Katz, 1980), in other words a two-step flow method (Ettlie and Elsenbach, 2007).

Overall our knowledge of the gatekeeper has broadened since Lewin's $(1947,1951)$ recognition of the term followed by Allen's (1977) much cited contribution, however the research fails to provide a measurable definition to characterise a gatekeeper's presence. However this research seeks to make a contribution methodologically, by using social network analysis and interview techniques to investigate how external knowledge emerges with rapid internationalising born globals (i.e. how do indigenous Irish born global animation companies network internationally), and in turn highlighting the gatekeeper in all case of applicable, as of course the gatekeeper is not the only means in which external knowledge enters the firm. However in the case of this research, the gatekeeper will receive specific attention. The next section provides an overview of the current Irish digital, film and TV production industry which provides the context for our study.

\section{The Irish digital, film and TV production industry}

Enterprise Ireland (2010) estimates that there are "more than 50 Irish animation companies offering a broad range of products and services to the worldwide entertainment market", this includes those involved solely in animation, TV/Film producers, advertising, flash and mobile content development and post-production houses. The animation industry in Ireland is the largest employer of full-time and permanent employees within the Irish film and TV sector (Enterprise Ireland, 2010), with a total of 337 employed in 2008 (Audiovisual Federation Review, 2009). It has also been noted that thirty seconds of animation, takes approximately one week of preparation, thus many productions take long periods of time (1-3 years) (Duncan, 2010).

The industry also contributes significantly to the Irish economy, with revenues increasing from $€ 13.5$ million in 2001 (Audiovisual Federation Review, 2004) to $€ 43$ million in 2009 (Audiovisual Federation Review, 2009) and as Duncan (2010) notes that the animation industry is a prime model of a "smart economy". These indigenous Irish companies are found investing money into the Irish animation sector, which builds the industry in the hope of securing long-term employment positions (Duncan, 2010). Table 1 provides an overview of the key players in the industry in the Irish context. These 15 firms comprised the population of our empirical study. 
Table 1 Founder and company profile overview

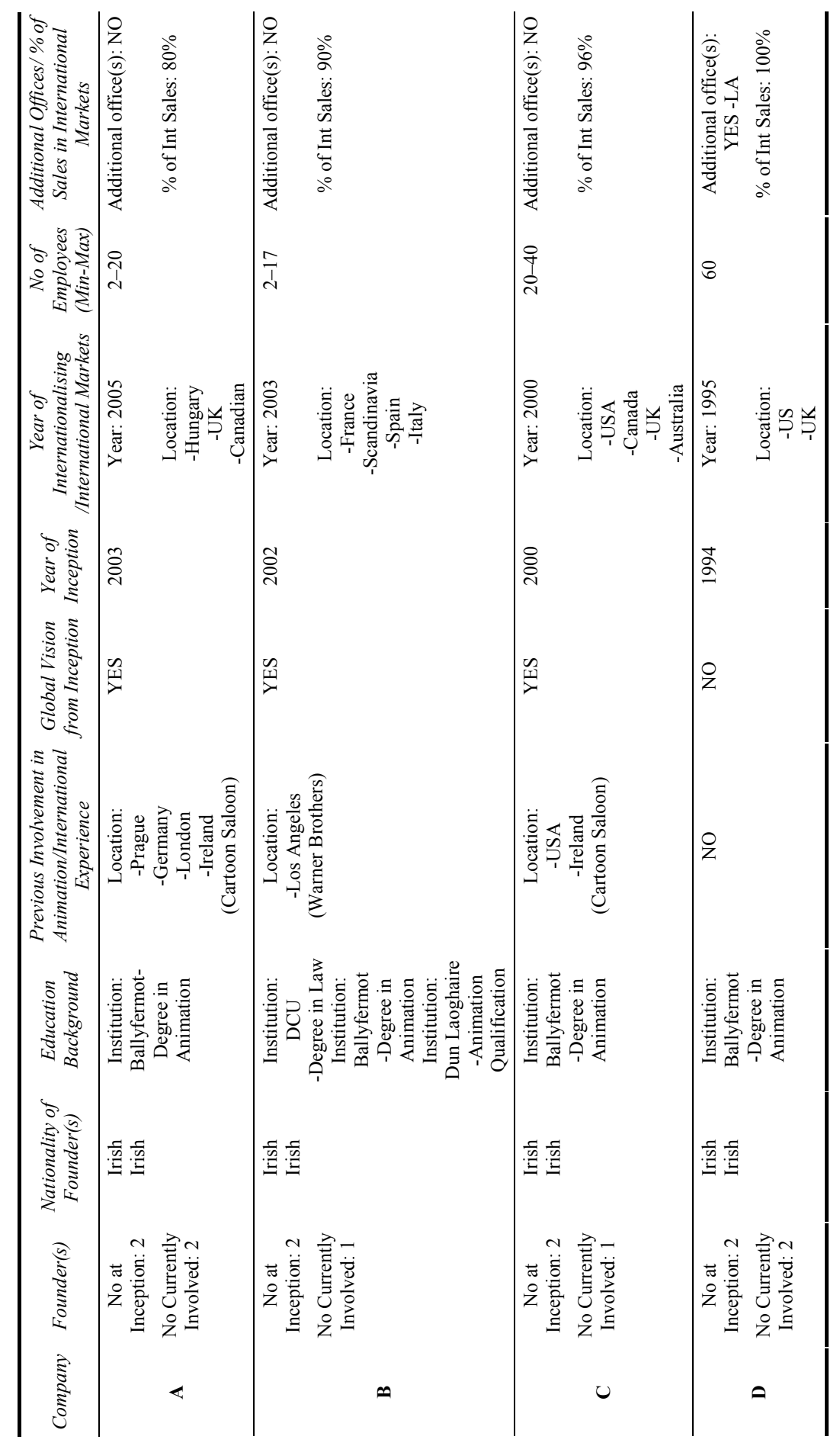


Table 1 Founder and company profile overview (continued)

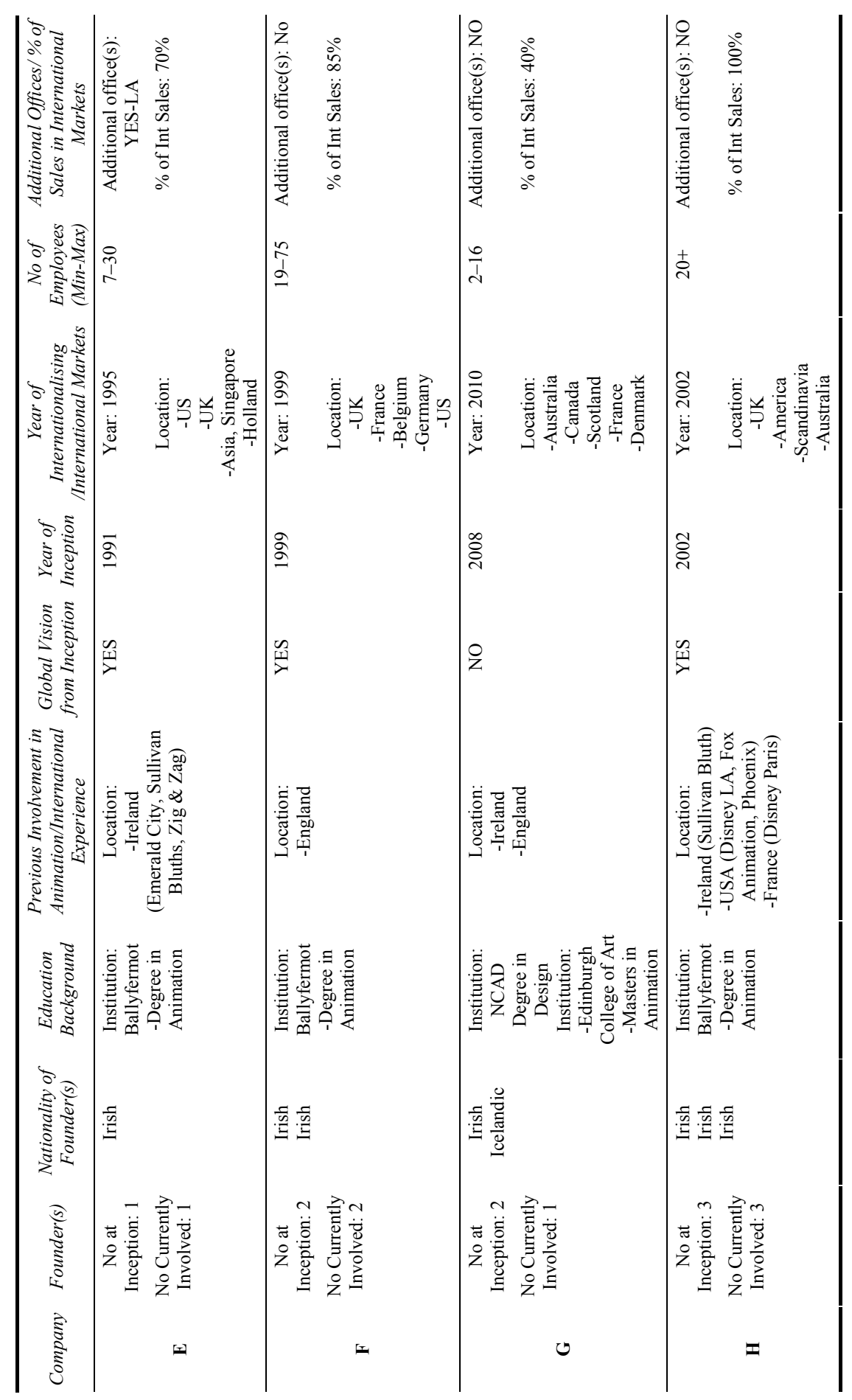


Table 1 Founder and company profile overview (continued)

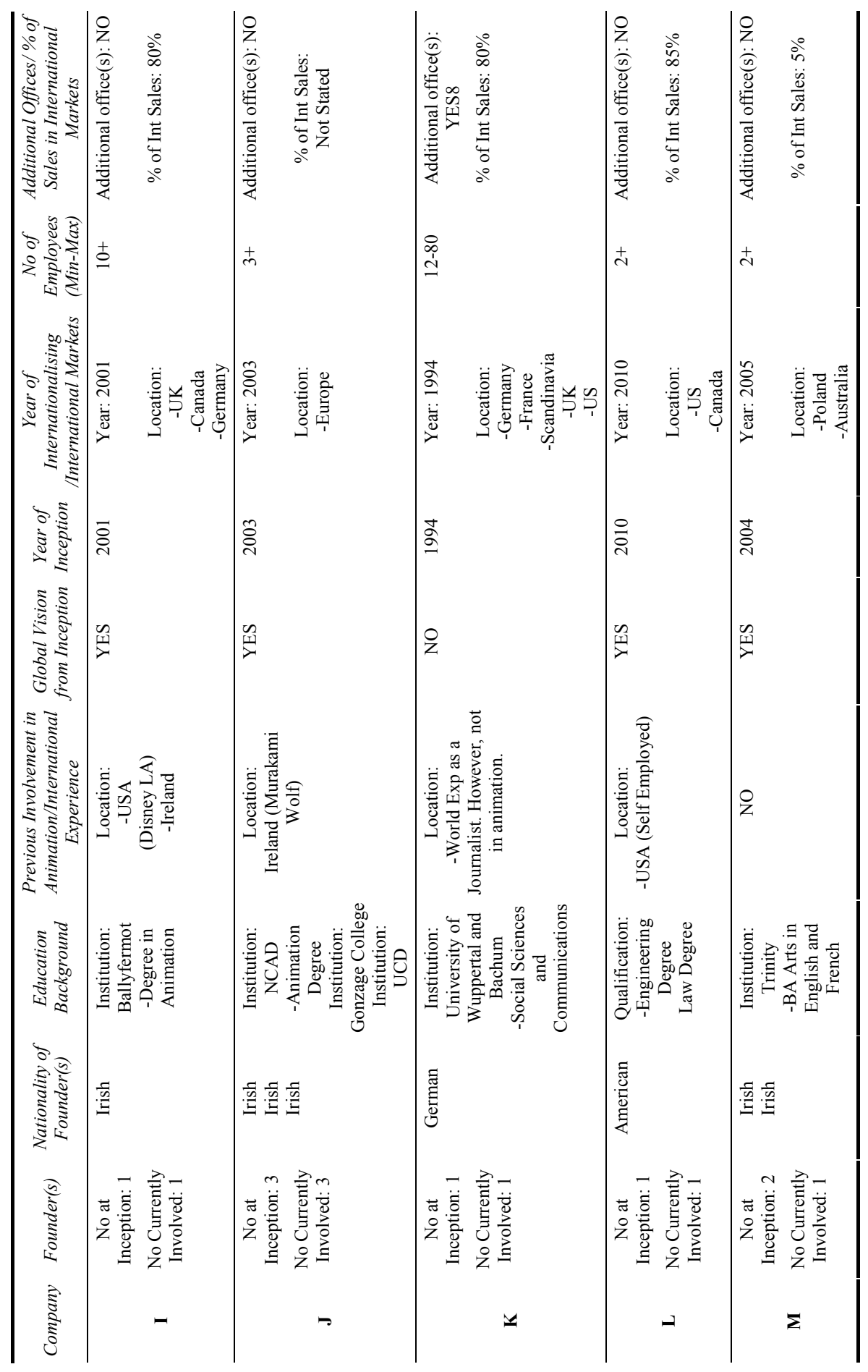


Table 1 Founder and company profile overview (continued)

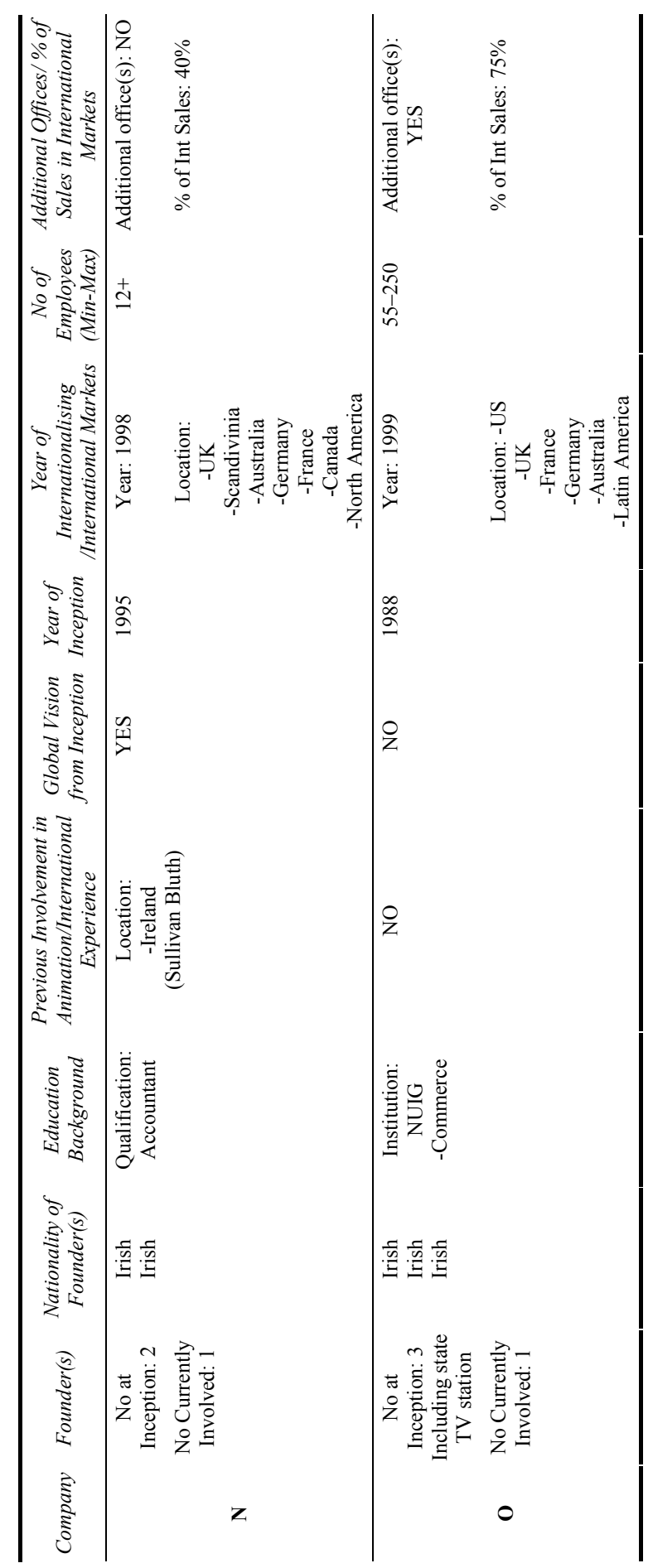


Even though the prospects for public funding in the sector look relatively bleak, the Irish Film Board remains positive regarding the future prospects including job growth (Audiovisual Federation Review, 2009). Further, as Collins (2010) notes "A tough environment and crisis can bring out the best". As a result of our current economic environment "Entrepreneurs have got hungrier, which is a good thing" (Collins, 2010; see also Smolarski and Kut, 2011). Notwithstanding these challenges the international reputation of the sector continues to flourish with the 2011 Children's BAFTA awards for Boulder Media. This is further and continuing recognition of the quality of the work produced in the Irish digital animation sector

\section{Methodological approach}

This study adopts a qualitative research approach to gather rich in-depth data, as part of a multi-phase research design. The primary means of data collection was semi-structured interviews, although data were also collected through press clippings, industry reports and company documentation and websites. The study adopts an established protocol, namely the case study method. A case study allows the examination of "a phenomenon in its natural setting, employing multiple methods of data collection to gather information from one of a few entities (people, groups or organisations). The boundaries of the phenomenon are not clearly evident at the outset of the research and no experimental control or manipulation is used" (Benbasat et al., 1987) and thus to facilitate understanding the dynamics present within a particular setting (Eisenhardt, 1989). Thus, the case study method is most appropriate to understanding the 'how' and the 'why', of a complex phenomenon (Yin, 1984; Yin, 1994) such as global networks.

Figure 4 outlines the research process adopted for the purpose of this study.

Figure 4 Research process (see online version for colours)

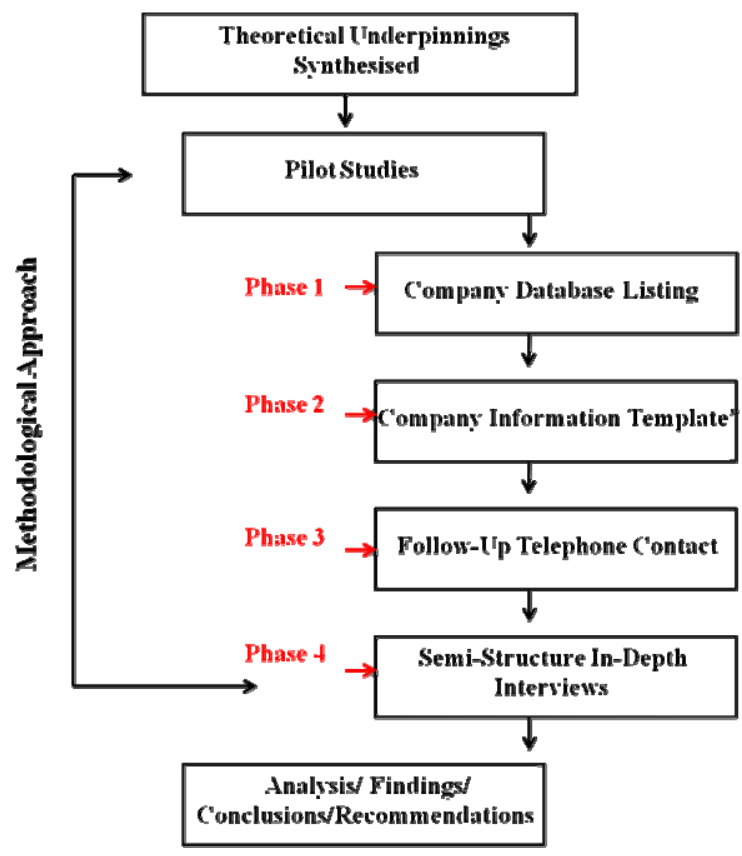


We chose Ireland as a focus of our study for a two important reasons. Firstly, with a small domestic market, it would not be possible for an animation company to be profitable without targeting international markets from an early stage. Hence it is quite likely that firms in the selection will be born globals. Secondly, although relatively small, the Irish animation sector has been remarkably successful over recent decades. While the initial growth of the industry was premised on a small number of international players attracted by significant tax breaks (all of whom have now left), more recently the sector has been driven by a number of key indigenous players. Collectively the work of these companies has garnered many high-profile awards including Oscars, Emmys, Cartoon Forum, ANNIE and Sundance, in addition to national entrepreneurship awards (Enterprise Ireland, 2010). Up until 2009 Ireland's film industry had achieved 45 international awards (Audiovisual Federation Review, 2009). These national and international successes mean the sector provides an interesting context for the study of the internationalisation of the firms.

The study process proceeded as now outlined. Firstly, a database of all Irish-based digital animation companies was assembled. The second phase involved developing a 'company information template' of the companies sourced, using secondary sources. However, in most cases there were remaining information gaps, thus the third phase of the research involved telephone communication with each company, in an attempt to satisfy the information gaps. This contact was also used as an introductory tool, which was further developed in the fourth phase of the research approach, the personal interview. The screening used in the selection process necessitated that a study firm met the following three criteria. It had to be:

1 Indigenous Irish.

2 Involved in the digital, film and TV production industry.

3 Involved in accelerated international operations.

Fifteen firms were targeted for the semi-structured in-depth interviews (see Table 1). All fifteen recognised suitable companies agreed to participate. In total 19 interviews were conducted with this group as in four companies two interviews were conducted with co-founders.

The semi-structured interview schedule covered a variety of issues and was structured in four principal sections. The first was the founders' profiles, second company profiles, third was extent of globalisation, customers and finally the nature of connectors and gatekeepers in their global network. The key themes which we explored were developed from our understanding of the extant literature on born globals combined with some specific insights from the sector. All interviewees were briefed in advance about the objectives of the research. During the interviews the respondents were asked to rank preprepared 'connectors' and add any omitted by the researcher team. They were also invited to sketch the network and identify connector strength by dint of heaviness of connection lines in the diagram. Additionally, we sought their permission to record their interviews (this was provided in all cases). Finally, in order to protect their anonymity we have not overtly identified interviewees in the presentation of our findings.

We now present the findings which illuminate the role which a menu of key connectors plays in the internationalisation of Irish animation firms. 


\section{Findings}

Our research identified a suite of 'connectors' for the Irish Digital, Film and TV Production firms that facilitate the internationalisation process within the networks for born globals. Included are those who are viewed as 'weak' connectors, and those who are considered 'strong'. The connectors are industrial, intuitional and state supports, agents and attendees and delegates at international festivals and tradeshows, and are built through prior international working experience and from positive word-of-mouth from previous clients. The born globals thus choose from the menu of connectors and have varying views on their utility, strong or weak, as levers for internationalisation of sales.

\subsection{Industry supports}

\subsubsection{Animation Ireland}

Animation Ireland is an 'umbrella brand', beneath which Ireland's leading animation enterprises organise and wherein the member firms work together to promote the animation industry. Its key personnel have an intimate knowledge of each animation company, and strenuously strive on their behalf for their international success. One founder states that 'they will set up meetings which kick-start new connections' (Co-Founder of Firm A). He also stated:

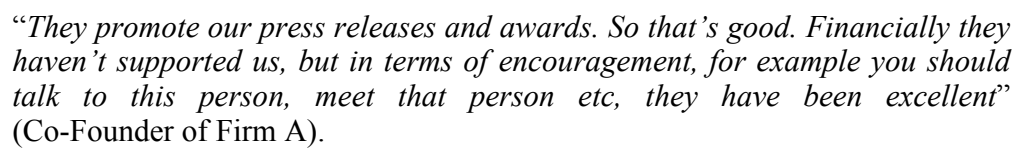

\subsubsection{The Irish film board (IFB)}

The IFB is a national organisation which has been developed to promote and support the talent, creativity and enterprise within the Irish Film Industry, of which digital animation is a key sub-unit. They are involved in the creative process of Irish films from script to screen whilst also providing investment for the development, production and release of Irish films, television, animation, documentaries and short films.

One founder stated that "we have been really happy with our dealings with the IFB. They recommended what festivals to go to and who to talk to. Over the years we have had lots of dealings with them" (Co-Founder of Firm A). Further to this the second Co-Founder of Firm A added, "they know more people than we do, and they pick out people you should meet so that you don't waste time meeting people that aren't going to do anything for you" (Co-Founder (B) of Firm A). Similarly, the Founder of Firm B highlighted that:

\footnotetext{
"They organise various events, for example at the Cork Film Festival they host various events which gives direction. They also host events that encourage networking and also they actually market our films for us.... so they are helping us get the films out there and draw interest. We deal with them an awful lot and they have been hugely important, without the Irish Film Board there would be no Irish animation industry. It's easy to say, you know they're just giving out money but, you know The Secret of Kells (Oscar nominated movie) would not have been made here if the Irish Film Board hadn't been involved. They promote through sales agents at festivals and they do raise the profile of Irish Films overseas dramatically" (Founder of Firm B).
} 
On the other hand, such positivity was not universal in the study population. As one disappointed founder reported, "They have not connected us internationally" (Founder of Firm K).

\subsection{Attendees and delegates at international festivals and tradeshows}

Festivals and tradeshows serve as fora where animators, screenwriters, directors and producers can network in meetings, at guest talks and at company trade stands. There are many such events held globally in locations such as Cannes, Berlin, Toronto and Venice. The Founder of Firm B outlines, "this is where I go to meet people that I need to.........it is the only connector that is getting the company out there".

Another respondent highlights that "Our mission is to talk to people that will either buy, or commission feature length projects, so that means TV stations or Theatrical distributors in different locations. We know this is where we will find them" (Founder of Firm D). While another similarly adds, "It's all about attending festivals and markets and meeting the right people. The international tradeshows and film festivals that we visit, Cannes, MIPCOM, these are where you build up your networks, where you go and have 40 meetings, many prearranged" (Founder of Firm H).

The Founder of Firm J explains, "....there is a big social element there too. You meet someone through someone... like in any walk of life really". International tradeshows and festivals are thus where the strongest connectors are to be found for these Irish Born Global Digital, Film and TV production companies.

\subsection{Agents}

Agents were also found to play a role in connecting Irish digital animation companies with customers internationally.

"It would have been an agent. He was the first initial guy that would have got us in there. He was there at the very start. He kind of got us introduced to all the big players in Hollywood and once you're in there, that's his job nearly done. So he was the one that helped us get our foot in the door and establish a connection" (Founder of Firm C).

Agents are principally used at the beginning of the internationalisation process and are believed to open doors but swiftly become considered uneconomic and less necessary.

\subsection{State and institutional supports}

\subsubsection{Enterprise Ireland}

Enterprise Ireland is a government agency engaged in helping the Irish-based animation companies progress to international markets. It supports such Irish companies from inception through to having an established presence in global markets. The respondents' views on the assistance of Enterprise Ireland were mixed. Several recognised Enterprise Ireland as a 'strong' connector, whilst in contrast others referred to them as 'weak' connectors. "I could survive without them. If they weren't there in the morning, I wouldn't miss them" (Founder of Firm O). The Founder of Firm H said "they would help us internally by funding, but they wouldn't connect us to businesses". While another interviewee states: 
"Well Enterprise Ireland used to be a strong connector, because the guy that used to work in the LA office of Enterprise Ireland is the Irish Film Board guy, however he is gone now. Enterprise Ireland work more as a facilitator. They aren't really establishing bonds" (Co-Founder of Firm F).

This comment particularly highlighted the importance of individuals within support organisations.

Another dismissively stated that "they have never connected us internationally" (Founder of Firm K). Even more disparaging of the agency was the following negative comment:

"I found Enterprise Ireland a nightmare. The problem with Enterprise Ireland is that they have very set ideas about what they think they do, and they really don't understand our business. A few do understand our business, but generally they are very unhelpful" (Co-Founder of Firm A).

Another very frustrated entrepreneur bemoaned the agency's bureaucracy and lack of understanding of 'creative':

"Enterprise Ireland gave me no money, no grant - nothing, never mind connecting me internationally. Like I had interviews with them twice, and they called me back in again, basically......just annoy me. I don't know what their deal is..... There is a lot of people sitting around filling out grant forms and jumping through all the hoops that Enterprise Ireland want to see written down in the forms. I don't know how to do all the jumps through the hoops and if I was to take time out to do it; I would probably lose business, just with focusing on that" (Founder of Firm G).

The principal inadequacy associated with Enterprise Ireland and its role in the international expansion of animation companies relates to lack of specific industry understanding. But despite this it was felt that the agency had a beneficial role to play as a connector for some firms:

"For example, last year at Kidscreen they organised a networking event. There was drinks and chats and that's all. In theory it's great, but it doesn't turn into an Irish drinking sessions, as we were restricted to a few hours. That's where you think, 'Ok what did I get out of that compared to what money was spent'. It's not that Enterprise Ireland aren't doing anything, it's just they might not be doing the right things. You look at what they have done and think 'the money you have spent here, would have been so much better spent at $X, Y, Z$. Overall, I think Enterprise Ireland are a big connector. I think they're still missing the boat a little bit in some stuff and I still think they're...you know...they're...it's a government body they're still going to have red tape and things like that...you know...that you're never going to get around. But would we be better off without them? - No there definitely is an advantage that they bring. Is there more they could do? Absolutely" (Founder of Firm E).

\subsubsection{FAS screen training Ireland}

FAS is a national training and skills development body which provides industry-relevant training programmes. It also provided access to industry insiders in one instance, but not deliberately. In fact, only one interviewee noted FÁS Screen Training Ireland as a connector but nonetheless regarded it as a 'strong connector'. 
"Someone else that I would also add into that is FAS. Their film division is called Screen Training Ireland and they are pretty important from a training aspect. But because of that, you might have a day with sales agents or you might have a day with distributors. You are going on a course for them to tell you how they act as a sales agent or a distributor. In effect it's a networking event because they might have five different distributors talking at the event. So in turn, they would have helped your company network. It's a huge benefit" (Co-Founder of Firm B).

\title{
5.4.3 Irish business and employer's confederation (IBEC)
}

IBEC was established in 1993 to provide a voice for business employers in Ireland. Their role involves supporting business interests and representing industry opinions. IBEC was found to play a minor role in the internationalisation process for the Born Globals in this study. Although one founder noted IBEC as a "strong" connector in relation to internationalisation and stated that they were "a very helpful bunch" (Founder of Firm O), the majority of other companies 'haven't had any dealings with them" (Co-Founder of Firm A). One of the respondents even stated that "I don't even know what that is...." (Founder of Firm G). This may simply be reflective of IBEC's actual role, given it is for mostly an Irish body supporting companies' domestic interests rather than connecting into the international market.

\subsection{Founders' previous employers and current client referrals}

Some interviewees identified 'previous employers' as important connectors. Half of the founders had international work experience in the animation sector prior to setting up their current enterprises. A variety of countries were founts of international experience with the greatest representation in the USA. This is to be expected given that Hollywood is the global hub of animation via renowned producers such as Disney and Warner Brothers. France, one founder stated that:

\begin{abstract}
"My main connectors are my connections with the States and that has been established from working there for three years. I go back there every year and I meet with them. I would usually go back every year with whatever short we'd made, or whatever I had in production, to get their feedback on it. It would be a kind of mentoring thing for me. We would sort of stay updated and keep that network alive and through that, meet new people and each time try and meet a different artist or try and find another aspect of the industry on the international side" (Founder of Firm B).
\end{abstract}

Germany, Czech Republic and the UK were other locations where individuals had gained experienced.

Positive 'word-of-mouth' gave rise to new connections via recommendations of the firms' craft and products. One Founder posited that "once you do one job it links to another and so on. Previous work brought us more work than anyone can imagine (Co-Founder of Firm A). Another respondent simply added "you have to build trust with others, and you only can do this by doing excellent quality work for them and as a result one job will lead to another" (Founder of Firm D). Likewise, another interviewee stated that 
"I think experience is the main thing, it's like once you have done one thing you will then get another. We have tended to grow steadily, in that we have done a small project, and then we have done one slightly bigger and then another a little bit bigger again. There is a definite progression. So like when we go to the next one, they can see, 'Ok they have managed this one perfectly well, they have a good project, brought it in on budget, on schedule'... you know. So that is a proven track record that you need to build. It's the next step in the ladder kind of thing" (Co-Founder 2 of Firm A).

International success in awards ceremonies led to even greater reputation capital. Firm E's Founder stated that:

"The Oscar nominations have benefited everybody you know...even though we haven't had any, it puts Ireland on the map and portrays this is a place of good quality" (Founder of Firm E).

Another founder likewise commented that:

"Ireland has had so many Oscar nominations, particularly this year and in previous years. Internationally they believe there is something creative about what is in the water in Ireland that no amount of money can buy" (Founder of Firm E).

\section{Discussion and conclusions}

The born global phenomenon represents an important stream of literature on the internationalisation of small firms. Previous work has identified four key elements in the globalisation process of born global firms (Andersson and Wictor, 2003). These focus on the entrepreneur themselves, the industry, globalisation and the network. We contend that, notwithstanding the contributions of Coviello and Munro (1995) and others, the role of the network in the globalisation process has been underexplored. Specifically, while Coviello and Munro (1995) have established the importance of the network in the globalisation process of born global firms, the underlying nature and processes of the connections within the network have not been unpacked to any significant degree. Thus, the network represents a kind of black box in the globalisation process. Though we know that connectors and gatekeepers are important in plugging the structural holes between the born global firm and their global customers in the globalised industry, we know far less about the process. We hope this study contributes to our understanding in this regard.

Our empirical study identifies that there are a suite of potential and important connectors in the internationalisation process of born global firms. These connectors are both strong and weak and born globals choose from that menu of connector options. Figure 5 establishes the born global 'networks', 'connectors', 'gatekeepers', 'actors' as well as the pronounced 'pathway' followed by those in the Digital, Film and TV Production industry progressing international.

The highlighted 'connectors' can also be referred to as 'gatekeepers' in this network, as such 'links' are strongly connected to both the born global organisation and the international marketplace. Individuals/organisations found in stage three are those involved in helping the flow of information between stage two and four. It has been established that these gatekeepers collect the relevant information from the companies in question and as an 'actor' process and share the information with the international market contacts. 
Figure 5 The digital animation global network

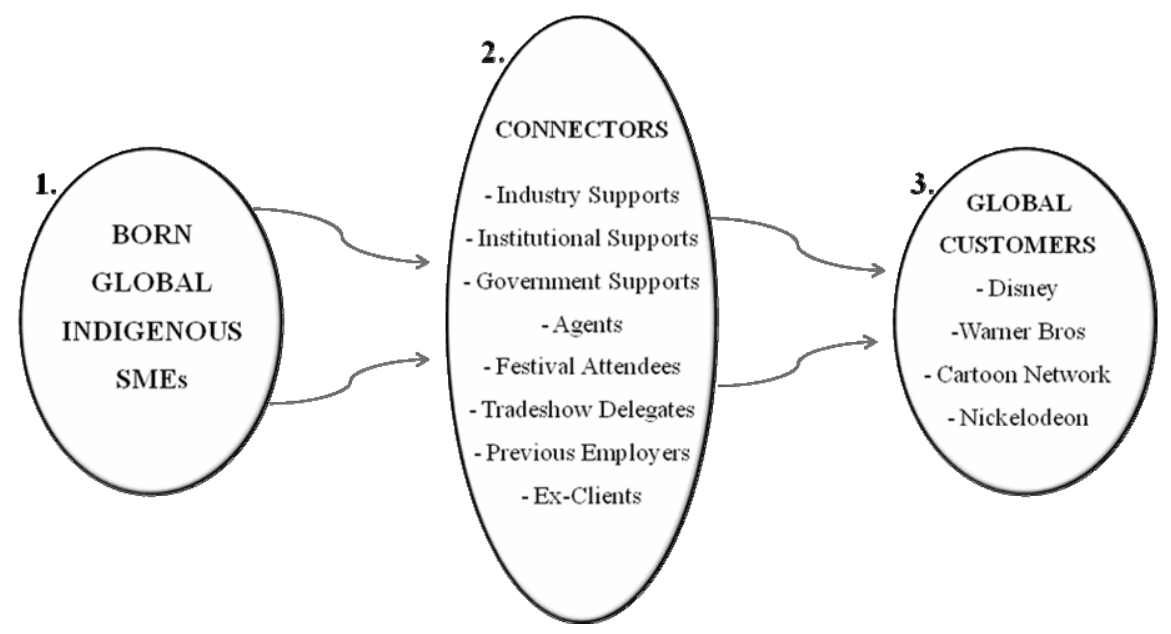

Coviello and Munro's (1995) work on networks and their relationship with internationalisation is reflected in our categorising of the different types of connectors, as is the work of Granovetter (1995) with regards to the importance of 'the strength of weak ties'. As Granovetter's (1995) theory suggests, the 'weak ties'/weak connectors proved much more valuable in terms of progression than 'strong ties'. As the theory predicts weak ties broaden the network of the born global firm in directions where it had not been before.

This study is limited in that the case study is on a distinctive and relatively unique sector. Further, given the study was conducted in a single country it would be interesting to explore how the nature of these global networks played out in firms of other nationalities. Notwithstanding this limitation, we do argue that our findings point to some important implications for born global firms emanating from a small domestic economy is a highly international industry. Future research could usefully endeavour to unpack the black box of further intrinsically born global sectors through some further qualitative study in different settings.

\section{References}

Allen, T.J. (1977) Managing the Flow of Technology, MIT Press, Cambridge, MA.

Allen, T.J. and Cohen, S.I. (1969) 'Information flow in research and development laboratories', Administrative Science Quarterly, Vol. 14, No. 1, pp.12-19.

Andersen, O. (1993) 'On the internationalization of process of firms: a critical analysis', Journal of International Business Studies, Vol. 24, No. 2, pp.209-231.

Anderson, J.C., Hakansson H. and Johanson J. (1994) 'Dyadic business relationships within a business network context', Journal of Marketing, Vol. 58, No. 4, pp.1-15.

Andersson, S. and Wictor, I. (2003) 'Innovative internationalization in new firms: born globals the Swedish case', Journal of International Entrepreneurship, Vol. 1, No. 3, pp.249-276.

Audiovisual Federation Review (2004) Film Production in Ireland, IBEC.

Audiovisual Federation Review (2009) Film and Television Production in Ireland, IBEC. 
Arrow, K. (1974) The Limits of Organisation, Norton, New York.

Barnes, J. (1954) 'Class and committees in a Norwegian Island parish', Human Relations, Vol. 7, pp.39-58.

Benbasat, I., Goldstein, D.K. and Mead, M. (1987) 'The case research strategy in studies of information studies', MIS Quarterly, September, Vol. 11, No. 3, pp.369-386.

Bell, S., Whitwell, G. and Lukas, B. (2002) 'Schools of thought in organizational learning', Journal of Academy of Marketing Science, Vol. 30, No. 1, pp.70-86.

Bilkey, W.J. and Teasar, G. (1977) 'The export behaviour of smaller-sized Wisconsin manufacturing firms', Journal of International Business Studies, Vol. 8, pp.93-98.

Burpitt, W. and Rondineli, D.A. (1998) 'Export decision-making in small firms: the role of organizational learning', Journal of World Business, Vol. 33, No. 1, pp.51-68.

Cavusgil, S.T. (1980) 'On the internationalisation process of firms', European Research, Vol. 8, pp.273-281.

Collins, J. (2010) Seven Firms Shortlisted for the Tech Awards. Available online at: www.irishrimes.com/newspaper/fiance/2010/0312/1224266101744_pf.html (accessed on 12 March 2010).

Coviello, N.E. and Munro, H.J. (1995) 'Growing the entrepreneurial firm: networking for international market development', European Journal of Marketing, Vol. 29, pp.49-61.

Czinkota, M.R. (1982) Export Development Strategies: US Promotion Policies, Vol. 1, Praeger, New York.

Davidson, W.H. (1980) 'The location of foreign direct investment activity: country characteristics and experience effects', Journal of International Business Studies, Vol. 11, No. 2, pp.9-22.

Dimitratos P. and Plakoyiannaki, E. (2003) 'On the conceptual underpinnings of an international entrepreneurial culture', Journal of International Entrepreneurship, Vol. 1, No. 2, pp.187-215.

Duncan, P. (2010) 'Irish Animators Drawing International Attention. Available online at: www.irishtimes.com/newspaper/finance/2010/0201/1224263503761_pf.html (accessed on 1 February 2010).

Eisenhardt, K.M. (1989) 'Building theories from case study research', Academy of Management Review, Vol. 14, No. 4, pp.1-14.

Enterprise Ireland (2010) Irish Animation Companies Shine at Kidscreen 2010 in New York. Available online at: http://americas.enterprise-ireland.com/irish-animation-companies-shineat-kidscreen-2010-in-new-york/ (accessed on 21 May 2010).

Erramilli, M.K., Srivastava, R. and Kim, S.S. (1999) 'Internationalisation theory and Korean multinationals', Asia Pacific Journal of Management, Vol. 16, pp.29-45.

Ettlie, J.E. and Elsenbach, J.M. (2007) The Changing Role of $R \& D$ Gatekeepers, Industrial Research Institute, Inc, pp.59-66.

Gabrielsson, M. and Kirpalani, V.H.M. (2004) 'Born globals: how do they reach new business space rapidly', International Business Review, Vol. 13, pp.555-571.

Gladwell, M. (2000) The Tipping Point: How Little Things Can Make a Big Difference, Little Brown, Great Britain.

Granovetter, M.S. (1973) 'The strength of weak ties', American Journal of Sociology, Vol. 78, No. 6, pp.1360-1380.

Granovetter, M.S. (1983) 'The strength of weak ties: a network theory revisited', Sociology Theory, Vol. 1, pp.201-233.

Granovetter, M.S. (1995) Getting a Job: A Study of Contact and Careers, University of Chicago Press, Chicago.

Haythornthwaite, C. (1996) 'Social network analysis: an approach and technique for the study of information exchange', Paper Presented at the ALISE Conference 1996, San Antonio, Texas. 
Hotho, S. and Champion, K. (2011) 'Small businesses in the new creative industries: innovation as a people management challenge', Management Decision, Vol. 49, No. 1, pp.29-54.

Hurmerinta-Peltomaki, L. (2004) 'Conceptual and methodological underpinnings in the study of rapid internationalizers', in Jones, M.V. and Dimitratos, P. (Eds): Emerging Paradigms in International Entrepreneurship, Edward Elgar, Cheltenham, UK, pp.64-88.

Huber, G. (1991) 'Organisational learning: the contributing processes and literature', Organisational Science, Vol. 2, No. 1, pp.88-115.

Hymer, S. (1960) The International Operations of National Firms: A Study of Direct Investment, $\mathrm{PhD}$ Dissertation, Sloan School of Management, Massachusetts Institute of Technology.

Johanson, J. and Vahlne, J. (1977) 'The internationalisation process of the firm - a model of knowledge development and increasing foreign market commitment', Journal of International Business Studies, Vol. 8, pp.23-32.

Johanson, J. and Vahlne, J. (2003) 'Business relationships learning and commitment in the internationalisation process', Journal of International Entrepreneurship, Vol. 1, pp.83-101.

Johanson, J. and Vahlne, J. (2009) 'The Uppsala internationalisation process model revisited: from liability of foreignness to liability of outer ship', Journal of International Business Studies, Vol. 40, pp.1411-1431.

Johanson, L. and Wiedersheim-Paul, F. (1975) 'The internationalization of the firm - four Swedish cases', Journal of Management Studies, Vol. 12, pp.305-322.

Johannisson, B. (1994) 'Building a global strategy. Internationalising small firms through local networking', Paper Presented at the 39th ICSB Annual World Conference, Strassbourg.

Katz, R. and Kahn, R. (1966) The Social Psychology of Organisations, Wiley, New York.

Lewin, K. (1947) 'Frontiers in group dynamics II. Channels of group life, social planning and action research', Human Relations, Vol. 1. pp.143-153.

Lewin, K. (1951) Field Theory in Social Science: Selected Theoretical Papers, Harper, New York.

Liesch, P. and Knight, G.A. (1999) 'Information internalization and hurdle rates in small and medium enterprise internationalization', Journal of International Business Studies, Vol. 30, pp.383-394.

Lopez, L.E., Kundu, S.K. and Ciravegna, L. (2008) 'Born global or born regional? Evidence from an exploratory study in the Costa Rican software industry', Journal of International Business Studies, Vol. 1, pp.1-11.

Madsen, T.K. and Servais, P. (1997) 'The internationalisation of born globals: an evolutionary process?', International Business Reviews, Vol. 6, No. 6, pp.561-583.

March, J. and Simon, H. (1958) Organisation, Wiley, New York.

Monge, P. and N. Contractor (2003) Theories of Communication Networks, Oxford University Press, Oxford, UK.

McDougall, P.P. and Oviatt, B.M. (2003) 'Some fundamental issues in international entrepreneurship', Entrepreneurship Theory and Practice.

Naranjo-Valencia, J.C., Jiménez-Jiménez, D. and Sanz-Valle, R. (2011) 'Innovation or imitation? The role of organizational culture', Management Decision, Vol. 49, No. 1, pp.55-72.

Oviatt, B.M. and McDougall, P.P. (1994) 'Towards a theory of international new ventures', Journal of International Business Studies, Vol. 25, No. 1, pp.45-64.

Oviatt, B.M. and McDougall, P.P. (1995) 'Global start-ups: entrepreneurs on a worldwide stage', Academy of Management Executive, Vol. 9, No. 2, pp.30-43.

Oviatt, B.M. and McDougall, P.P. (2005) 'Defining international entrepreneurship and modelling the speed of internationalization', Entrepreneurship Theory and Practice, Vol. 29, No. 5, pp.537-553.

Rasmussen, E.S., Madsen, T.K. and Evangelista, F. (2000) 'The founding of the born global company in Denmark and Australia: sense making and networking', Asia Pacific Journal of Marketing and Logistics, Vol. 13, No. 3, pp.75-107. 
Reid, S.D. (1981) 'The decision-maker and export entry and expansion', Journal of International Business Studies, Vol. 12, pp.101-112.

Rugman, A.M. (1981) Inside the Multinational: The Economics of Internal Markets, Croom-Helm, London.

Shoemaker, P. (1991) Gatekeeping, Sage, Newbury Park, CA.

Smolarski, J. and Kut, C. (2011) 'The impact of venture capital financing method on SME performance and internationalization', International Entrepreneurship and Management Journal, Vol. 7, No. 1, pp.39-55.

Teece, D.J., Pisano, G. and Shuen, A. (1997) 'Dynamic capabilities and strategic management', Strategic Management Journal, Vol. 18, No. 7, pp.509-533.

Thompson, J.D. (1967) Organisations in Action, McGraw Hill, New York.

Tushman, M. and Katz, R. (1980) 'External communication and project performance: an investigation into the role of gatekeepers' Management Science, Vol. 26, No. 11, pp.289-305.

Tushman, M. and Scanlan, T. (1981) 'Boundary spanning individuals: their role in information transfer and their antecedents', Academy of Management Journal, Vol. 24, No. 2, pp.289-305.

Vivian, N. and Sudweeks, F. (2003) 'Social networks in transnational and virtual communities', Informing Science, InSITE - 'Where Parallels Intersect', 24-27 June, Pori, Finland.

Weerawardena, J., Mort, G.S., Liesch, P.W. and Knight, G. (2007) 'Conceptualising accelerated internationalisation in the born global firm: a dynamic capabilities perspective', Journal of World Business, Vol. 42, pp.294-306.

Yin, R.K. (1984) Case Study Research: Design and Methods, 1st ed., Sage Publishing, Beverly Hills, CA.

Yin, R.K. (1994) Case Study Research: Design and Methods, 2nd ed., Sage Publishing, Beverly Hills, CA.

Zahra, S.A. and George, G. (2002) 'International entrepreneurship: the current status of the field and future research agenda', in Hitt, M.A., Ireland, R.D., Camp, S.M., and Sexton, D.L. (Eds): Strategic Entrepreneurship: Creating a New Mindset, Blackwell Publishers, Oxford. 